\title{
LUT
}

University

\section{A framework of disruptive sustainable innovation: an example of the Finnish food system}

Kuokkanen Anna, Uusitalo Ville, Koistinen Katariina

This is a Author's accepted manuscript (AAM) version of a publication

published by Taylor \& Francis

in Technology Analysis \& Strategic Management

DOI: $10.1080 / 09537325.2018 .1550254$

Copyright of the original publication: (c) Taylor \& Francis 2018

Please cite the publication as follows:

Kuokkanen, A., Uusitalo, V., Koistinen, K. (2018). A framework of disruptive sustainable innovation: an example of the Finnish food system. Technology Analysis \& Strategic Management. DOI: 10.1080/09537325.2018.1550254

This is an Accepted Manuscript of an article published by Taylor \& Francis in Technology Analysis \& Strategic Management on 26.11.2018, available online: http://www.tandfonline.com/ DOI: $10.1080 / 09537325.2018 .1550254$

This is a parallel published version of an original publication. This version can differ from the original published article. 
A framework of disruptive sustainable innovation: an example of the Finnish food system

Kuokkanen Anna ${ }^{\text {a*; }}$ V. Uusitalo ${ }^{\text {a. }}$ K. Koistinen ${ }^{\mathrm{a}}$

${ }^{a}$ Sustainability Science, LUT University, Lahti, Finland

*Saimaankatu 11, Lahti 15140, Finland: anna.kuokkanen@lut.fi 


\section{A framework of disruptive sustainable innovation: an example of the Finnish food}

system

Disruptive innovations are perceived necessary for accelerating sustainability transitions. However, it is not always clear what exactly is meant by it, what is to be disrupted, and by whom. Socio-technical transition research on pays too much attention at the technological niche-innovations in the production, and overlooks business model innovation and user practices in the consumption, whilst management literature on disruptive innovation falls short in the scale and scope of disruption in terms of systemic outcome. Thus, the first aim of the paper is to synthesize the extant literature and put forward a general practice-based view on disruptive sustainable innovation. The second aim of the paper is to use empirical data to elaborate the theoretical framework in the Finnish food system context. Four firm-level cases provide empirical scrutiny to each type of disruptive sustainable innovation in the food system and shed light on the interlinked practices of producer-entrepreneurs and citizen-consumers.

Keywords: sustainability transitions; disruptive innovation; disruptive sustainable innovation; food system; food system innovation. 


\section{Introduction}

The incumbent food consumption and production systems require transition towards more sustainable food systems. Sustainability transitions are systemic changes in the entire configurations of mobility, energy, and agri-food systems, which entail technological artefacts, policy, markets, user practices, infrastructure, cultural meanings and scientific knowledge (Geels, 2004). Socio-technical transitions occur via multi-level interaction between radical niches and an incumbent regime, both of which are nested in and affected by an external landscape (Geels, 2004). Regime level reflects mainstream system functioning with established rule structure and networks, which is reinforced by path dependency (Markard, et al., 2012). In contrast, niches are the locus of experimenting, emergence of new rules and practices, learning, alternative technologies and consumption patterns (Schot \& Geels, 2008). Niche level has a less coercive rule structure, with less rigid networks and alignments, and is therefore better suited to the development and testing of radical novelties (Geels, 2004). Transitions require new type of innovations, which do not aim to improve the resilience of the existing regimes but to transform them in order to avoid pushing the earth system beyond the planetary boundaries (Westley \& al., 2011).

Incremental innovation, developed within the incumbent regime and aligned along the existing trajectories, can only lead to smaller, and largely insufficient, sustainability gains (Geels, 2004). Whilst, innovation that is based on disruptive technologies, creating completely new markets and replacing incumbents (Christensen, 1997), is developed outside the coerciveness of the incumbent regime (Geels, 2004). As disruptive innovation destabilizes the existing regime, it can enable the emergence of new, more sustainable patterns of production and consumption (Westley \& al., 2011). 
Disruptive innovation has become a 'buzzword' used in both research and practice (Johnstone \& Kivimaa, 2018). In the field of sustainability transformation in e.g. energy system, high expectations are placed on disruptive innovations to solve climate crisis and other environmental problems. Nevertheless, it occurs from a recent special issue on Disruptive Innovation and Energy Transformation, that the term is highly contested and deserves more analytic clarity and research (Wilson \& Tyfield, 2018).

The aim of the paper is to build a framework for understanding disruptive innovation for sustainability transition in the food system. We do this by approaching two streams of literature, business and management literature and socio-technical transition research. Based on the extant literature and the gaps in it, we propose a practice-based view on disruptive sustainable innovation. Consequently, we use four firm-level cases that represent each category in the framework to elaborate on the proposed framework in the empirical context of the Finnish food system.

\section{Theoretical framework}

\subsection{Disruption in socio-technical transitions}

Many consumption and production systems, like energy and food systems, have strong path-dependencies and lock-ins. Lock-in implies that sustainability transitions require disruptive action, even purposeful destabilization (Geels, 2014). Transition research has particularly emphasized the role of radical technical niches in disrupting incumbent socio-technical systems. The focus on niches has broadened from merely technical innovations to consumer niches (Smith, 2007), and only recently to niches 
employing new business models (e.g. Uber, Airbnb) (Boons, et al., 2013). The interest lies in how new technologies come about, how emerging technologies can be up-scaled, or how user preferences can be directed towards more sustainable patterns. Still majority of niches are focusing on improving resource efficiency per unit basis on the supply side, and do not include consideration of sufficiency in the consumption side (Mont \& Plepys, 2008). Without the accounts of quantity, quality and patterns of final consumption rebound effects seem to trump the efficiency gains achieved per unit of production (Weidmann, et al., 2015; Nykvist \& Whitmarsh, 2008; Kyba, et al., 2017).

For sustainability transitions, both the pace and the direction of change are equally important. It is a dual challenge of not only changing the provision system (transportation, agriculture, energy), but also the criteria that actors use to judge the appropriateness of products, services, and systems (Kemp \& van Lente, 2011). Geels (2018) suggests to clarify between the speed of change (gradual vs. disruptive) and the outcome of change (large or small change in socio-technical systems), and goes on to argue that large system change can occur also gradually, and not only through disruptive and revolutionary change, as often is the assumption. Paying more attention at alignments and co-evolution of technology and society can reveal dynamics of gradual change. Much of the transition literature focuses on innovation dynamics, i.e. how change takes place, but equally important is the focus on 'issue dynamics', i.e. problem definition and socio-political mobilization (Geels, 2018).

Niche-oriented view on disruption tends to either over-emphasize the role of technology, or treat the agency of consumers from a very individualist perspective (Spaargaren, 2011). Focusing on technological innovations at the production side run 
the risk of disregarding user-practices and hence not achieving the intended environmental benefits (Blok, et al., 2015). Focusing on consumer behaviour can place too much responsibility on citizen-consumers, overlooking the limitations of political consumerism and constraints of existing systems of provision (Shove, 2010). The intertwined relationship between the technology and users, or between production and final consumption, is under-conceptualized, but can be overcome by a focus on practices (McMeekin \& Southerton, 2012). This can also provide better understanding of disruptive innovation for systemic sustainability transition.

Another shortcoming has been an inadequate attention at the role of individual firms in the change of entire systems (Boons, et al., 2013). Particularly, when the agency is not only channelled into the existing corporate responsibility reporting or improving energy and resource efficiency, but into radically transforming the system itself (Loorbach \& Wijsman, 2013). Firms and their activities can influence and shape sustainability transitions purposefully (York \& Venkataraman, 2010), by shifting the market they operate in and transforming their own business (Loorbach \& Wijsman, 2013).

\subsection{Disruptive innovation in business and management}

Christensen's idea of disruptive innovation originally aimed to highlight a mechanism, by which lead firms' close relationship with lead users make them vulnerable to disruption, as they overlook the potential of more massive low-end users (Christensen, et al., 2015). Technological learning within the low-market segment can lead to the alternative option becoming dominant. Hence, in his notion disruptive 
innovation originates from capturing non-users or under-served users. In 2003, Christensen extended the idea to encompass also innovation that captures markets that previously did not exist (Christensen \& Raynor, 2003). Christensen distinguishes disruptive and sustaining technology in terms of their attractiveness to end users (attributes related to markets and users), whilst radical - incremental characterizes the extent of technological advancement or breakthrough (attributes about technological improvements). Whilst sustaining technologies improve the performance of established products, along the dimensions of performance that mainstream-users value, the disruptive technologies bring a very different value proposition than has been available previously (Christensen, 1997). Disruptive innovations are often competencedestroying, making incumbent firms' competences obsolete and hence contributing to the decline of the prevailing socio-technical regime (Anderson \& Tushman, 1990).

Disruptive innovation can be broken down into at least three sub-categories: disruptive technological, business-model and product innovation (Markides, 2006). Markides (2006) defines disruptive business model innovation as the discovery of a fundamentally different business model in an existing market. According to Markides (2006), to qualify as an innovation, the new business model must enlarge the existing market, either by attracting new customers into the market or by encouraging existing customers to consume more. Whereas disruptive technological innovation, based on Christensens' view, eventually replace incumbent firms, business model innovations usually co-exist with the established business models. Another type of disruptive innovation is a radical product innovation, which is disruptive to both consumers and producers. A new product or value proposition disturb established consumer practices 
and undermine the competences and complementary assets of the existing producers (Markides, 2006).

While disruptive innovation has a well-established definition in business and management literature, in the context of sustainability transitions it has contrasting interpretations (Wilson \& Tyfield, 2018). In a special issue of Disruptive Innovation and Energy Transformation, Wilson and Tyfield (2018), categorize three different streams of perspectives around the questions of scale and scope. In the narrowest scope, disruptive innovation focuses on technologies and business models, in which disruptive innovation offers an alternative to mainstream forms of service provision and incumbent service providers. This interpretation is closest to the original Christensen's definition of disruptive innovation. The focal point in the second stream is socio-technical systems. It challenges the first stream of disruptive innovation by embedding change within the broader system and multi-level interaction, as oppose to 'point source' view on disruption (Geels, 2018). A third streams goes beyond mere technology or systems focus, and explores disruption as a form of continuity and discontinuity narratives, politics and power. Cumulated incrementalism, in which incumbents play an important role, results in transformation, just as the disruptive dynamics do (Winksel, 2018). Moreover, by definition disruption is not necessarily a desired objective: innovation for disruption and innovation forced by environmental or economic disruptions have very different connotations (Kramer, 2018). Whilst the third stream makes important points about the macro scale, we focus particularly on the first two to elaborate disruptive innovation in the context of sustainability transformation. 
There is a need to make a clear distinction between general disruptive innovation and disruptive innovation for sustainability transformations (later on, disruptive sustainable innovation, DIS). The latter have some distinguishable features compared to the generic disruptive innovation. For instance, disruptive low-carbon innovations in the energy system usually offer the same functionality or attributes for end users with more efficient or low carbon substitutes for the incumbent forms of energy production, distribution or use (Wilson, 2018). DIS are distinctive by displacing or transforming the existing system functions with the emission-reduction or sustainability-increasing outcome. Disruptive potential of innovation is also systemspecific, so that, in the transport system, it may imply a shift away from a personal vehicle based mobility, while for the energy system it implies a shift away from centralised fossil fuel based production to decentralised renewable energy (Sprei, 2018). Therefore, to summarize, Christensen's original definition of disruptive innovation falls short in terms of systemic sustainability transition in three most critical dimensions: (1) scales of disruption and continuity; (2) limits of niche-based view on routes of disruption; and (3) innovation related to public goods (McDowall, 2018).

\subsection{Practice-based view on disruptive sustainable innovation}

Shifting the focus on practices can avoid the agency-structure and agencytechnology dualism (Spaargaren, 2011), and provide a broader understanding of what is to be disrupted and by whom. Practices, as the unit of analysis, see Figure 1, are shared and collective and thus avoid putting an individual in the centre, while the agency is not dismissed, as actors are those who produce and reproduce them within certain structures and specific systems of provision (Spaargaren, 2011). In this view, disruption is born at 
the interface, connecting producer to user, or grower to eater in the food system. New technologies, products or services are disruptive when they enable and manage to change user practices towards more sustainability. Simultaneously users' changing expectations and demands can incite new business models and value offerings, thus changing producer-entrepreneurs practices.

\section{Figure 1.}

Food system is a good example of a system, in which consumers' decisions are normalized everyday practices, meaning that actions are a produce of facilitating conditions, routines and behavioural intentions (Triandis, 1977). These practices emerge from the socio-technical regime structure and actors' participation in the regime. Hence, disruption cannot be reduced to a single event of 'adoption' but is a more subtle change of citizen-consumers' daily practices. For instance, a recent Finnish study found that more than $50 \%$ of food consumers are potentially 'green', but the strategies to mobilize them are very different depending on different consumer profiles (Salonen, et al., 2014). Salonen et al. (2014) identified eight consumer profiles depending on their external vs internal motivation, and altruistic vs egoistic motivation, see Table 1.

\section{Table 1.}

According to Salonen et al. (2014) the biggest consumer segments are the 'Caretakers', the 'Bystanders', and the 'Devoted' ones. Out of these the 'Caretakers' and the 'Bystanders' are extrinsically motivated, yet while the latter are late-comers, the 'Caretakers' are moving towards the altruistically and intrinsically motivated position, given the right triggers, and are thus the gatekeepers of social change. These are 
followed by the 'Ambitious', the 'Dreamers' and the 'Uncompromising' ones. The 'Ambitious' and the 'Dreamers' are egoistically motivated, meaning that they prioritize personal benefits such as health and better performance, yet while 'Dreamers' follow the crowds, the 'Ambitious' ones purchase more ecologically and socially responsible products and services in pursue of more holistic lifestyles. They also influence professionally by launching value-driven start-ups and ventures. The smallest, but influential, consumer segments are the 'Curious' and the 'Autocrats' ones. As egoistic and hedonistic, the 'Autocrats' are trendsetters, whilst the 'Curious' are relatively independent and critical consumers who aim to do sensible decisions based on the information available. The 'Uncompromising' and the 'Devoted' ones are the most responsible consumers and driven by intrinsic and altruistic values and pursue of holistic lifestyles. In terms of disruption, it is important to notice that those who are extrinsically motivated can be influenced, and they represent enormous potential $(53,5 \%)$. Yet, while others are influenced with more information, others are driven by emotions and product's quality attributes other than merely environmental ones (Salonen, et al., 2014).

The identified consumer profiles illustrate the socially differentiated groups that understand and engage in the same practice of food consumption in variable ways (McMeekin \& Southerton, 2012; Warde, 2005). Subsequently, these groups have differentiated ways of changing and gradually disrupting daily practices. The intrinsically motivated are likely to go to further lengths in acting according to their values, and hence they are more likely to self-reflect their user practices in a holistic way. In contrast, extrinsically motivated are likely to be more affected by external marketing and find sustainable products and services more attainable, e.g. by replacing 
some of their consumption with plant-based products. In both cases, disruption is also dependent on multiplicity and diversification of practices related to sustainable food (Warde, 2005). The more sustainability and sustainable products and services infiltrate across places and practices, the more prevalent they become. Therefore, practice-based approach provides tools for understanding the processes, through which forms (and the volume) of consumption are reproduced and change (McMeekin \& Southerton, 2012).

In regards to producer-entrepreneurs' practices, Boons and Leudeke-Freund (2013) highlight how business models link the activities of firms to the larger systems of which they are part of and hence relate to sustainability transitions:

(1) The value proposition makes explicit the relationship between the firm and its customers based on exchange of value, be it social, ecological or economic.

(2) The configuration of value capture and the consequent revenue model, which connects the firm to suppliers and customers and the realizing costs and benefits.

Sustainability-driven value proposition or value capture strategy sets producerentrepreneurs apart from the others in the market. Sustainable value proposition can be distinguished by high quality, long-term focus and need-orientation (Bergset \& Fichter, 2015). Value capture strategies can differ in the level of market-orientation, i.e. involving non-traditional economic approaches, the growth willingness and the control and decision-making rights, e.g. cooperatives (Bergset \& Fichter, 2015). Based on these characteristics Bergset \&Fichter (2015) put forward five different types of start-ups, see Table 2. Start-up types are distinguished based on the extent of market orientation in contrast to sustainability concerns at their value offering and value capture strategy. For the ecopreneurial and the unintentionally green start-ups sustainability is externally motivated opportunity, as they are primarily economically and market-oriented. The inventive start-up tries to balance between an economic and a sustainability-related 
orientation, as they pursue solving sustainability problems through their invention and business. The alternative and the visionary start-ups are explicitly sustainability-driven and have transformative attitude towards their business (Bergset \& Fichter, 2015). Radically different value propositions and value creation strategies are the ways, in which these sustainable businesses compete but also actively engage in disrupting existing patterns of production and consumption. Sustainability-driven entrepreneurs can create more radical innovations, for their motivation may lie exactly in challenging the legitimacy of incumbent businesses and institutions by doing things they do not do (York \& Venkataraman, 2010; Dyllick \& Muff, 2016).

Table 2.

Building on the previous sections, Table 3, outlines a general framework of practice-based disruptive sustainable innovation. Disruptive sustainable innovation can either substitute the existing practices with an emission-reducing or sustainabilityincreasing outcome, or transform the existing practices with new attributes. Innovation can be based on a different value offering or a different value capture strategy. Disruptive potential is system-specific, meaning that one needs to understand, which practices are critical in a specific system in regards to system's sustainability, and which attributes are not sustainable in the incumbent system.

Table 3.

The main practices in the food system are production, distribution, and consumption. The main environmental issues with production are land use change, water eutrophication due to high use of chemical fertilizers and pesticides, loss of 
biodiversity, and soil degradation due to monocultures. Distribution encompasses both transportation and retail, and is characterized with increasingly global supply chains and consolidated retail market. The main issues relate to the food waste and losses along the supply chain and emissions from transportation. Also the lack of transparency, integrity, and traceability are often cited concerns related to modern food supply chains. The main issues with consumption are non-sustainable diets, including high consumption of meat and dairy products, and high amounts of waste and food losses generated at retail, food services and households. Incumbent food systems are decoupled from seasonality, are highly standardized, and have constant availability and abundance of product brands (Horlings \& Marsden, 2011). These are just some attributes to keep in mind. For sustainable innovation to be disruptive, it must enable collective change of existing practices and/or attributes associated to them.

\section{Materials and methods}

\subsection{Research approach}

Practice-based view on disruptive sustainable innovation is an emergent and underdeveloped theory, and as such requires further theory elaboration (Fisher \& Aguinis, 2017). In addition, due to the technology-bias of sustainability transition literature, food consumption and production system provides a novel context for studying disruptive innovation. Theory elaboration differs from theory generation in using pre-existing conceptual ideas or emergent models for developing new theoretical insights (Fisher \& Aguinis, 2017). Theory elaboration aims to contextualize a general 
theory, yet instead of using empirical data for testing theory, it is used to challenge it (Ketokivi \& Choi, 2014). Theory elaboration has three main implementation approaches and seven tactics of conducting a study (Fisher \& Aguinis, 2017). In contrasting approach, researcher can contrast theoretical construct horizontally, contrasting to a different context, or vertically, contrasting to a different level of analysis (Fisher \& Aguinis, 2017). Contrast specification tactics include advancing theory by identifying and defining new constructs, or splitting existing constructs based on observed empirical data (Fisher \& Aguinis, 2017). According to Fisher \& Aguinis (2017) the third approach, is structuring by specific relations, by sequence or by recursive interaction.

Herein, we use the general framework of practice-based view on disruptive sustainable innovation in the Finnish food system context, and use empirical data to inform and shape the different types of disruptive sustainable innovation. The vertical axis that describes the dimensions of disruption (displacement of existing functions vs new attributes to existing functions) have been generated in the mobility and energy system context (Wilson, 2018; Sprei, 2018). Here, we use horizontal contrasting to the Finnish food system context, what displacement of or new attributes to the existing functions implies in the food system context. The horizontal axis describes the 'place' of disruption, whether it is in the value proposition or value capture strategy (Boons \& Leudeke-Freund, 2013). We use the general theoretical framework to identify the cases, whilst simultaneously using empirical cases to inform and specify the construct. In firmlevel cases, we focus particularly on practices of producer-entrepreneurs and citizenconsumers by interrogating their interlinkages. 
Empirical data is collected in order to elaborate on the dimensions of disruption in the Finnish food system and on the other hand on the practice-based change between producer-entrepreneurs and citizen-consumers. The aim is to scrutinize empirically the types of disruptive sustainable innovation and the interaction between producerentrepreneurs and citizen-consumers in each category. Firm-level cases are chosen so that they stand for each type of disruptive sustainable innovation (see Table 1). In addition, they are small- or medium-sized enterprises from different parts of the food value chain. They also have an explicit focus on sustainability. Each case study included site visit, an in-depth interview, and environmental life-cycle assessment. The results of the life-cycle assessment are only referred to, but not explicitly presented here, as they are presented in the separate publications: case Kauppahalli24 (Koistinen, et al., 2017), case Särkifood (Uusitalo, et al., 2018), case Ompputonttu (Uusitalo, et al., manuscript), and case Lahti Food Co-op (Hintukainen, et al., manuscript).

\subsection{The Finnish food system}

Finnish food system is largely comparable to those in most western countries, with some local peculiarities. Finland has an extensive agricultural sector with 2,3million ha arable land (8\% of land under cultivation), almost 50000 farms with an average of 46 ha/ha, and high self-sufficiency in most staple products (89-105\% own production in terms of consumption) (Natural Resources Institute Finland, 2016). However, agricultural sector produces only a fraction of national income, less than $2 \%$ of GDP (Niemi \& Ahlstedt, 2015). Agricultural production is subject to European Common Agricultural Policy (CAP), and the majority of producers are under national agri-environmental protection scheme. It is indicative that almost $(2 / 3)$ of producers' 
income comes from different forms of subsidies and is not market-driven (Natural Resources Institute Finland, 2016). Since joining EU, agricultural sector has significantly improved its productivity through economies of scale and consolidation, yet the average unit size remains small in comparison to European level. In addition, other parts of the agri-food value chain have streamlined and consolidated, making the food value chain oligopolistic (few actors control majority of the market share) (Kuosmanen, et al., 2009). Particularly the retail sector, dominated by only two big chains, has increased its profitability since joining EU (Kuosmanen, et al., 2009). In recent years, this has sparked lots of debate in the media, as producers are feeling financially increasingly squeezed by the retail sector, leading to farmers' demonstration in 2016, while retailers compete by offering cheaper prices.

The Finnish food system faces similar sustainability challenges as elsewhere in the western countries. Due to the long coastline at the fragile Baltic Sea, nutrient runoff has been one of the main environmental issues, which has created a lock-in of food system into unsustainable nutrient economy (Kuokkanen, et al., 2016). However, there also other concerns. Land use change and monocultures are responsible for biodiversity losses (Aakkula \& Leppänen, 2014). High reliance on imported fertilizers, energy and feedstock affect food security (Niemi, et al., 2013), and rising consumption of animalbased products has higher climate and environmental impact (Natural Resources Institute Finland, 2018). Unethical treatment of animals and producers' wellbeing are some of the social concerns that food system is regularly accused of.

\section{Disruptive sustainable innovation in the Finnish food system}


Four firm-level cases allowed us to identify four types of disruptive sustainable innovation in the Finnish food system. This section presents each type of innovation at a case-level and as embedded in the broader Finnish food system context. Empirical data allowed us also to scrutinize how practices of producer-entrepreneurs and citizenconsumers change in each category of the innovation. These identified categories, see Table 4, are not exhaustive, and solely reflect the Finnish food context, but can be used as a basis for comparative studies.

Table 4.

\subsection{T1: Case Särkifood: alternative protein-source products}

Särkifood is a start-up company that aims to produce 'burger patties' from roach fish. Roach fish is considered a waste fish and hence is not a popular catch. Many eutrophicated lakes, such as Lake Vesijärvi in Lahti region, have excessive amounts of roach. Thus, roach fishing removes excessive nutrients and mitigates nutrient runoffs. In comparison to other sources of protein, roach fish has insignificant environmental impacts (Uusitalo, et al., 2018). Producing ready-to-cook patties can make them more accessible for consumers and more feasible environmentally-oriented business. Even though roach fish patties are not suited for vegans and lacto-ovo-vegetarians, they can occasionally replace meat consumption. Särkifood aims to provide a familiar massconsumption product from local biomass, which is considered waste, but which collection can have positive impact on the environment in terms of water quality, biodiversity and climate change. Hence, for a consumer it broadens the selection of protein sources with a highly environmentally efficient product and offers a service of 
cleaning the local lake. Despite roach fish patties have negligible impact in comparison to beef patties, consumers are only occasionally likely to replace beef patties for roach ones. For user-consumers roach fish patties, and other alternative protein sources, displace some portion of meat- and dairy-based proteins in their diets, whilst for producer-entrepreneurs they change the expectations of value offering from high impact to low impact proteins. Särkifood is an example of a business case, in which the value offering is based explicitly on solving an environmental problem with a technical invention. This can be classified as an inventive start-up, which is driven by highly inventive and technically skilled entrepreneurs (Bergset \& Fichter, 2015). These types of businesses do not aim to change all at ones, but to solve one problem at a time. In addition, given the appeal to broader consumer segments, it can have bigger impact.

It has been evident for a long time now that meat consumption is among the biggest environmental issues in the food system. The most recent publication concluded that vegan diet is perhaps the single biggest way to reduce individuals' overall environmental impact, as animal production has huge effects not only on greenhouse gases, but also on land use, freshwater use, water pollution and air pollution (Poore \& Nemecek, 2018). Changing dietary habits away from meat-based products has been difficult and very slow. However, in the 2017 one of the leading retail chains, Kesko, estimated that the volume of plant-based protein products has increased by $20 \%$, and is more than 50\% higher than two years ago (Talouselämä, 2017). This is mainly due to the boom in oat- and fava bean-based replacements for grounded meat, and oat-based milk and dairy products. Various reasons and their combined impact is behind their market disruption, but one major factor is that they managed to expand the market by attracting those customers that are not necessarily vegan or vegetarian, and have never 
tried plant-based protein alternatives. On the other hand, roach patties can attract all types of consumer profiles, as they do not require drastic dietary shifts or intrinsic and altruistic motivation (Salonen, et al., 2014). Their advantage is that they provide the exact same function and attributes to the end users except that they do not have as big environmental impact. Insects have gained lots of attention as a new and exotic protein source, and since the change of legislation, insect products are available in normal supermarkets.

\subsection{T2: Case Kauppahalli24: alternative distribution chains}

Kauppahalli24 is an online-based grocery store. Their offering is different compared to traditional shops because food can be bought online and delivered directly to homes, saving the shopping time. In terms of sustainability transition, they can change the basic logic of retailing, by offering local, seasonal and smallholders' produce, as they do not need to have the same volume as often required at the traditional supermarkets. In addition, they do not need to have big storages and long storing times as they can deliver food according to the ordering and producers' availability. Naturally, their main challenge lies in the logistics, emissions of which depend on various factors, but overall can lead to emission reductions if planned according to systematic approach (Koistinen, et al., 2017). Particularly with increasing digitalization, flexible pricing, and smart logistics, supply chain can be optimized not only in terms of transportation but also food waste and losses. The Kauppahalli24 case represents an ecopreneurial startup, which primarily aims to capture an emerging market opportunity and potential to grow in a short period (Bergset $\&$ Fichter, 2015). As sustainability and environmental issues are raising public attention, there is an increasing amount of business 
opportunities. The 'Kauppahalli24' consumers are likely to be those that are externally and egoistically motivated. For this consumer profile, sustainability may be of interest, when it is more convenient, timesaving, or trendy (Salonen, et al., 2014).

Two biggest retail chains comprise over $80 \%$ of the Finnish food supply chain (Päivättäistavarakauppa ry, 2017). In the past years, this has generated different public concerns. Particularly, low producer prices have turned attention to the market domination of retail chains, and given a boost to revitalization of 'local food' and alternative supply chains, such as direct farm sales and online grocery shopping. Online grocery shopping can be potentially disruptive if it dismantles the role of retailers as gatekeepers between producers and consumers, and reduces transportation and storage needs. Digitalization, flexible pricing and smart optimization can also reduce food waste and losses. Both retail chains have launched their own online grocery shops and have expanded their delivery range. Despite growing interest towards online grocery shopping and shorter supply chains, they are still marginal on the market, e.g. online grocery shopping has grown from 26 million€ to 57 million€ in $2015-2017$, but still stands for only about $0,5 \%$ of total sales (Tammilehto, 2018).

\subsection{T3: Case Ompputonttu: sustainable production}

Ompputonttu is an organic sheep farmer-entrepreneur that explicitly states that their entire business is value-laden, meaning that it is ideological and uncompromising. Not only their farm is certified organic, but their sheep graze at biodiversity hotspots and take care of culturally important sites, as well as obtain nutrient cycle and soil carbon. Ompputonttu perceives their role more as an environmental steward than as a 
business-for-profit (Bocken, et al., 2014). Customers, and they do not like to use this term, are only one stakeholder group among many others, and do not only pay for the kilogram of organically and ethically produced sheep meat but also for all the values and benefits they create. Most of their customers buy the meat directly from their farm, so that they are able to see where and how it is produced, and to see the live animal they are going to eat. The price of meat is significantly higher than if bought at the supermarket. However, this way consumers face a more realistic and comprehensive costs of producing meat, and most likely eat less of it.

The case of Ompputonttu aims to challenge the attributes of the incumbent production. Moreover, it does not aim to solve one environmental problem, but to take into account environment in a more holistic and integral way. It is likely that their customers are similarly minded and strive towards more sustainable lifestyles overall. Ompputonttu represents a case, in which the value is based on a multi-functionality of an organic farm, transparency of production and engagement with the community and society. It can be classified as the visionary start-up, which aims to change the world (Bergset \& Fichter, 2015; Linnanen, 2002), and challenge the existing regime by deliberately acting in a different logic than the mainstream businesses.

Modern industrial food production is usually based on large-scale monocultures, with high use of chemical fertilizers and pesticides to maximize yields, and little transparency to end users. Industrial food production is often alleged with socially unethical practices. Many of these attributes are either directly or indirectly linked to why incumbent food systems are considered not sustainable. This has created various different production philosophies, such as biodynamic, regenerative, ethical, and 
organic production. Out of these organic has become the predominant antidote to mainstream industrial production. Organic farming relies on ecological methods to maintain soil fertility and weed control, and it avoids using chemicals and pesticides. Since it is certified, it is more transparent in terms of production methods. It is also considered cleaner, safer and environmentally friendly, thus challenging the incumbent attributes associated to conventional production. Organic food sales have grown steadily, being 273 million€ in 2016 , yet still representing only few percent of the total food sales (ProLuomu, 2017). The more important fact is that almost a third of all consumers buy organic products at least once a week, and more than half of population buy organic products regularly (ProLuomu, 2017). This shows that attributes associated to organic production have disruptive potential, and can become prevalent. In fact, incumbent retailers' private label are starting to have organic, ethical and environmental labels, indicating growth of the market. Their business attracts particularly intrinsically and altruistically motivated consumer groups (Salonen, et al., 2014). However, it may also attract those who value very high quality or wants to stand out, such as high-end restaurants.

\subsection{T4: Case Lahti Food Co-op: community-oriented food}

Lahti Food Co-op produces bio-dynamically grown vegetables in their community garden. The main idea is to grow locally as much vegetables and greens as possible. In addition to an open field, they have one greenhouse, because otherwise the growing season in Finnish weather conditions would be too short. Co-op is not a business in a traditional sense as it does not act for profit, but they do want to be seen as business as they are dependent on economic feasibility. Their aim is not only to produce sustainable 
greens and vegetables but also to challenge the prevailing food retailing, consumption, community engagement and modes of doing business. In addition to co-op membership they sell shares of annual harvest, which varies year by year, and require $2 \mathrm{~h}$ of labour contribution (which can also be compensated with money). Citizen-consumers have to learn to the idea of sharing the harvest and the variation of harvest from year to year. Through labour contribution, they also get acquainted with growing their own food.

Lahti food co-op is based on the community-supported agriculture (CSA) model, which aims to be an alternative socio-economic model of agriculture and food distribution allowing risk-sharing between producer and consumer (Cone \& Myhre, 2000). As a co-op they operate as not for profit, and hence can be classified as an alternative start-up, which deliberately challenges the conventional market economy (Bergset \& Fichter, 2015). One of its explicit aims is to provide avenues for more active citizen engagement, and hence its' members are likely to be intrinsically and altruistically driven who are looking for more than just nutrients to eat (Salonen, et al., 2014).

In the modern food system majority of consumers are passive recipients and dependent on food coming from the supermarkets. Any supply shock or market distortion can have major effects on food security, while long supply chains alienate consumers from where and how food is grown and produced. Consumption has also changed from cooking wholesome meals at home to eating processed food, halffabricates and fast food, which is manifested by rush and time-saving. Eating has also lost some of its social aspect as consumer research indicates that Finnish people spend less time eating together than elsewhere, and almost all missed the sense of community 
(Ministry of Forestry and Agriculture, 2016). In contradiction to fast and easy food, community-oriented initiatives provide social networks, food sovereignty, and attachment to growing, harvesting and cooking from scratch. Particularly, urban and community gardens are becoming more popular. As they are usually also noncommercial, they change an entire set of attributes associated to the incumbent food system and especially consumers' role in it from passive to active.

\section{Discussion}

\subsection{Disruptive sustainable innovation}

The aim of the paper was to synthesize what is meant by disruptive innovation when used in the context of systemic sustainability transition. The term is ubiquitously used in both research and practice without necessarily clarifying what is meant by it. Various scholars agree that the original Christensen's definition of disruptive innovation is undoubtedly limited and narrow for sustainability transformations (Wilson \& Tyfield, 2018; Wilson, 2018; McDowall, 2018; Geels, 2018). Whilst sustainability transition literature has a technological niche and production-oriented bias towards disruption, disregarding agency of entrepreneurs and citizens which shape and reshape production and consumption practices (Spaargaren \& Oosterveer, 2010; McMeekin \& Southerton, 2012; Blok, et al., 2015). Hence, we put forward a practice-based view on disruptive sustainable innovation. The framework differentiates between how the innovation is disrupting prevailing regime, and where the disruption occurs. Innovation can be disruptive by displacing existing practices by new ones or by redefining the attributes related to the existing practices. It can occur in the value offering, which pinpoints 
consumers' needs and the functions that are fulfilled by the value offering, or value capture strategy, which connects producers to their suppliers and consumers (Boons \& Leudeke-Freund, 2013). The framework should be contextualized in order to define what ultimately can be considered a disruptive sustainable innovation. Whilst disruptive innovation is mainly concerned with how incumbent firms get replaced by new entrants, disruptive sustainable innovation deals with which existing functions are disrupted or which attributes are transformed with more sustainable ones. It is more interested in the content and the outcome of the innovation than merely the process.

Here, the importance is placed at assessing the change of practices instead of merely assessing the efficiency gains of a single product or a technology at the production. For instance, meat-replacement products may not be based on disruptive technological innovations, but when their market share starts to compete with animalbased products, they can have a major systemic effect. Of course, quantitative estimation of generated sustainability benefits is sensitive to chosen parameters and is not necessarily all-encompassing. However, accounting for change of practices, and not simply assessing the efficiency of an individual technology or a process, could deliver information that is more meaningful to policymakers, businesses and citizen-consumers. Identification of consumer profiles, particularly those that are gatekeepers, can accelerate disruptive change.

Looking at the disruptive innovation either as a novel value proposition or as a different value capture strategy connects end users to the firm level, yet leave room for their agency. For instance, despite all case-firms are potentially disruptive sustainable innovations, they have different entrepreneurial motivations and business models. At 
the same time, they also do not attract the same citizen-consumer profiles or influence on the same citizen-consumer practices. Thus, the overall impact is not necessarily as much in the content as such, but it is rather dependent on how large share of practices are influenced and how large are the reinforcing spill-over affects. For instance, in the case of Kauppahalli24 and Särkifood, bigger market players are entering the market, anticipating disruptive change. Also, their appeal to not only intrinsically and altruistically motivated citizen-consumers implies a potentially bigger market. Meanwhile, cases of Ompputonttu and Lahti Food Co-op, which are rather sustainability than market oriented, and aim to challenge attributes of existing food system functions in a comprehensive way, attract only intrinsically and altruistically motivated citizen-consumers. Nevertheless, despite their very marginal market potential in terms of size they expand the 'market' in terms of scope. As Geels (2018) noted, systemic transitions can occur gradually. Hence, identifying and focusing on shifts in practices can signal larger scale regime disruption, which is not by default going towards higher sustainability. Weak signals are important for businesses and start-ups, but also for public officials and policymakers if they aspire purposeful regime destabilization (Geels, 2014).

\subsection{Policy and practice}

It is not at all indifferent how the term disruptive (sustainable) innovation is used in policy and practice. It has an effect on policies, investments, and research and development funding, which steers the overall direction to change. One can think of how much funding goes into the development of more efficient production technology in comparison to consumption and sufficiency oriented innovations. This despite the 
fact that in terms of sustainability, limiting or displacing incumbent consumption patterns, preferences, and quantities have one of the biggest potential (Mont \& Plepys, 2008). Of course, the outcome of the innovation is not pre-determined and can take socio-technical systems along entirely unpredictable trajectories. Nevertheless, the way disruptive (sustainable) innovation is defined and used, influences the way we envision the future and the expectations we hold for innovations. Broadening this understanding is essential also because digitalization and new technological breakthroughs are dramatically changing the dynamics of production and consumption, enabling e.g. more circular and sharing economy models. Many technological start-ups are creating useroriented service innovations, while employing radically different business models. This provides enormous potential to the existing production and consumption systems. However, incumbent actors, which business still relies on unsustainable levels and patterns of consumption, are not likely to be the ones harnessing this potential.

\section{Conclusions}

Sustainability transitions require innovations that disrupt both production and consumption practices. However, original definition of disruptive innovation is too limited to capture systemic change perspective, being also biased towards radical technology innovation at the production side. To overcome these shortcomings, we propose a practice-based framework for disruptive sustainable innovation. Practicebased view bridges on the one hand, production and consumption perspectives, and on the other hand, producer-entrepreneurs and citizen-consumers agency. Based on the theory elaboration in the Finnish food system, we identified four types of disruptive sustainable innovation: (1) alternative protein-source products, (2) alternative 
distribution chains, (3) sustainable production and (4) community-oriented food. We also presented a firm-level case for each of the categories, shedding light on differentiated approaches in the entrepreneurial and user practices. In the following stage, the aim is to quantitatively asses the disruptiveness of each innovation, which could broaden analytic and prescriptive tools for sustainability transition research and policy. Finally, disruptive (sustainable) innovation can be useful theory, if more attention is paid at specifying its meaning in a given socio-technical context.

Acknowledgements:

This paper was produced in the project funded by the European Regional Development Funding. Reviewers' comments have been very valuable in improving this paper.

References:

Aakkula, J. \& Leppänen, J., 2014. Follow-up study on the impacts of agri-environment measures (MYTVAS 3) - Final report, Helsinki: Ministry of Agriculture and Forestry.

Anderson, P. \& Tushman, M., 1990. Technological discontinuities and dominant designs: a cyclical model of technological change. Administrative Science Quarterly, Volume 35, p. 4.

Bergset, L. \& Fichter, K., 2015. Green start-ups - a new typology for sustainable entrepreneurship and innovation research. Journal of Innovation Management, 3(3), pp. 118-144.

Blok, V. et al., 2015. From best practices to bridges for a more sustainable future: advances and challenges in the transition to global sustainable production and consumption: Introduction to the ERCSP stream of the Special volume. Journal of Cleaner Production, Volume 108, pp. 19-30.

Bocken, N., Short, S. \& Evans, R., 2014. A literature and practice review to develop sustainable business model archtypes. Journal of Cleaner Production, Volume 65, pp. 42-56. 
Boons, F. \& Leudeke-Freund, F., 2013. Business models for sustainable innovation: state of the art and steps towards a research agenda. Journal of Cleaner Production, Volume 45, pp. 9-19.

Boons, F., Montalvo, C., Quist, J. \& Wagner, M., 2013. Sustainable innovation, business models and economic performance: an overview. Journal of Cleaner Production, Volume 45, pp. 1-8.

Christensen, C., 1997. The Innovator's Dilemma: When New Technologies Cause Great Firms to Fail. Boston, MA: Harvard Business School Press.

Christensen, C. \& Raynor, M., 2003. The innovator's solution: creating and sustaining succesful growth. Harvard Business Review Press.

Christensen, C., Raynor, M. \& McDonald, R., 2015. What is disruptive innovation. Harvard Business Review, Volume December, pp. 44-53.

Cone, C. \& Myhre, A., 2000. Community-supported agriculture: A sustainable alternative to industrial agriculture?. Human Organization, 59(2), pp. 187-197.

Diaz, R. \& Rosenberg, R., 2008. Spreading dead zones and consequences for marine ecosystems. Science, 321(5891), pp. 926-929.

Dyllick, T. \& Muff, K., 2016. Clarifying the meaning of sustainable business: Introducing a typology from business-as-usual to true business sustainability. Organization and Environment, 29(2), pp. 156-174.

Fisher, G. \& Aguinis, H., 2017. Usign theory elaboration to make theoretical advancements. Organizational Research Methods, 20(3), pp. 438-464.

Geels, F., 2004. From sectoral systems of innovation to socio-technical systems: Insights about dynamics and change from sociology and institutional theory. Research Policy, 33(6), pp. 897-920.

Geels, F., 2014. Regime resistance against low-carbon transitions: Introducing politics and power into the multi-level perspective. Theory, Culture \& Society, 31(5), pp. 21-40.

Geels, F., 2018. Disruption and low-carbon system transformation: Progress and new challenges in socio-technical transitions research and the multi-level perspective. Energy Research \& Social Science, Volume 37, pp. 224-231.

Godfray, H. et al., 2010. Food Security: The challenge of feeding 9 billion people. Science, 327(5967), pp. 812-818. 
Horlings, L. \& Marsden, T., 2011. Toward the real green revolution? Exploring the conceptual dimensions of a new ecological modernisation of agriculture that could 'feed the world'. Global Environmental Change, Volume 21, pp. 441-452.

Johnstone, P. \& Kivimaa, P., 2018. Multiple dimensions of disruption, energy transitions and industrial policy. Energy Research \& Social Science, Volume 37, pp. 260-265.

Kahiluoto, H. et al., 2014. Taking planetary nutrient boundaries seriously: Can we feed the people?. Global Food Security, 3(1), pp. 16-21.

Kemp, R. \& van Lente, H., 2011. The dual challenge of sustainability transitions. Environmental Innovation and Societal Transitions, 1(1), pp. 121-124.

Ketokivi, M. \& Choi, T., 2014. Renaissance of case research as a scientific method. Journal of Operations Management, Volume 32, pp. 232-240.

Koistinen, K., Uusitalo, V. \& Huostila, A., 2017. Systematic approach to sustainability of novel internet-based system for food logistics. Logistics \& Sustainable Transport, 8(1), pp. 50-61.

Kramer, G., 2018. Energy scenarios - Exploring disruption and innovation. Energy Research \& Social Science, 37: pp. 247-250.

Kuokkanen, A. et al., 2016. The need for policy to address the food system lock-in: A case study of the Finnish context. Journal of Cleaner Production, Volume 140, pp. 933-944.

Kuosmanen, T., Niemi, J. \& Sipiläinen, T., 2009. Maataloustuen ja tuottavuuden vaikutukset elintarvikkeiden hintamarginaaleihin ja hinnanmuodostukseen, Jokioinen: MTT.

Kyba, C. et al., 2017. Artificially lit surface of Earth at night increasing in radiance and extent. Science Advances, 3(11), p. e1701528.

Linnanen, L., 2002. An insider's experiences with environmental entrepreneurship. Greener Management International, Theme issue Environmental Entrepreneurship, Volume 38, pp. 71-80.

Loorbach, D. \& Wijsman, K., 2013. Business transition management: exploring a new role for business in sustainability transition. Journal of Cleaner Production, Volume 45, pp. 20-28.

Markard, J., Raven, R. \& Truffer, B., 2012. Sustainability transitions: an emerging field of research and its prospects. Research Policy, 41(6): pp. 955-967. 
Markides, C., 2006. Disruptive innovation: in need of better theory. Product Innovation Management, Volume 23, pp. 19-25.

McDowall, W., 2018. Disruptive innovation and energy transitions: is Christensen's theory helpful?. Energy Research \& Social Science, Volume 37, pp. 243-246.

McMeekin, A. \& Southerton, D., 2012. Sustainability transitions and final consumption: practices and socio-technical systems. Technology Analysis \& Strategic Management, Volume 24, pp. 345-361.

Mekonnen, M. \& Hoekstra, A., 2016. Four billion people facing severe water scarcity. Science Advances, 2(2), p. e1500323.

Ministry of Forestry and Agriculture, 2016. Syödään yhdessä, s.1.: Ministry of Forestry and Agriculture.

Mont, O. \& Plepys, A., 2008. Sustainable consumption progress: should we be proud or alarmed?. Journal of Cleaner Production, 16(4), pp. 531-537.

Natural Resources Institute Finland, 2016. Luke Tilastotietokanta. [Online] Available at: http://statdb.luke.fi/PXWeb/pxweb/fi/LUKE/LUKE__02\%20Maatalous_ $02 \% 2$ ORakenne $\quad 02 \% 20$ Maatalous\%20ja\%20puutarhayritysten\%20rakenne/06_Maatalous_ja_puutarhayrit_keskim _kmm.px/table/tableViewLayout1/?rxid=001bc7da-70f4-47c4-a6c2c9100d8b50db

[Accessed 1212 2017].

Natural Resources Institute Finland, 2018. Balance Sheet for Food Commodities. [Online]

Available at: http://stat.luke.fi/en/balance\%20sheet $\% 20$ for $\% 20$ food\%20commodities [Accessed 2 July 2018].

Niemi, J. \& Ahlstedt, J., 2015. Suomen maatalous ja maaseutuelinkeinot 2015, Helsinki: Natural Resources Institute Finland.

Niemi, J., Knuuttila, M., Liesivaara, P. \& Vatanen, E., 2013. Finland's food security and maintenance and supply security: The current situation and future prospects, Helsinki: MTT.

Nykvist, B. \& Whitmarsh, L., 2008. A multi-level analysis of sustainable mobility transitions: Niche development in the UK and Sweden. Technological Forecasting and Social Change, 75(9), pp. 1373-1387. 
Poore, J. \& Nemecek, T., 2018. Reducing food's environmental impacts through producers and consumers. Science, 6392(360), pp. 987-992.

ProLuomu, 2017. Luomun myynti lisääntyy - yli miljoona suomalaista ostaa viikottain. [Online]

Available at: https://proluomu.fi/luomun-myynti-lisaantyy-yli-miljoonasuomalaista-ostaa-viikoittain/ [Accessed 5th June 2018].

Päivättäistavarakauppa ry, 2017. pty.fi. [Online]

Available at: https://www.pty.fi/julkaisut/tilastot/ [Accessed 5th June 2018].

Salonen, A. et al., 2014. Sustainable consumption in Finland - The phenomenon, consumer profiles, and future scenarios. International Journal of Marketing Studies, 6(4).

Schot, J. \& Geels, F., 2008. Strategic niche management and sustainable innovation journeys: theory, findings, research agenda, and policy. Technology Analysis \& Strategic Management, 20(5), pp. 537-554.

Shove, E., 2010. Beyond the ABC: Climate change policy and theories of social change. Environment and Planning A, 42(6), pp. 1273-1285.

Smith, A., 2007. Translating sustainabilities between green niches and socio-technical regimes. Technology analysis \& strategic management, 19(4), pp. 427-450.

Spaargaren, G., 2011. Theories of practices: Agency, technology, and culture. Exploring the relevance of practice theories for the governance of sustainable consumption practices in the new world-order. Global Environmental Change, Volume 21, pp. 813-822.

Spaargaren, G. \& Oosterveer, P., 2010. Citizen-consumers as agents of change in globalizing modernity: the case of sustainable consumption. Sustainability, 2(7), pp. 1887-1908.

Sprei, F., 2018. Disrupting mobility. Energy Research \& Social Science, Volume 37, pp. 238-242.

Talouselämä, 2017. Vegemyynti kovassa kasvussa - Kasviproteiinituotteiden lisäksi kuluttajia kiinnostaa ei-maito. Talouselämä, 9th June.

Tammilehto, P., 2018. Kesko laajentaa elintarvikkeiden verkkokaupan kotiinkuljetuksia. Kauppalehti, 6th March.

Triandis, H., 1977. Interpersonal behavior. Monterey, CA: Brooks/Cole. 
Warde, A., 2005. Consumption and theories of practice. Journal of Consumer Culture, 5(2): pp. 131-154.

Westley, F. \& al., e., 2011. Tipping towards sustainability: emerging pathways of transformation. AMBIO: A journal of the Human Environment, 40(7), pp. 762780.

Wiedmann, T. et al., 2015. The material footprint of nations. PNAS, 112(20), pp. 62716276.

Wilson, C., 2018. Disruptive low-carbon innovations. Energy Research \& Social Science, Volume 37, pp. 216-223.

Wilson, C. \& Tyfield, D., 2018. Critical perspectives on disruptive innovation and energy transformation. Energy Research \& Social Science, Volume 37, pp. 211215.

Winksel, M., 2018. Beyond the disruption narrative: Variaties and ambiguities of energy system change. Energy Research \& Social Science, 37: pp. 232-237.

York, J. \& Venkataraman, S., 2010. The entrepreneur-environment nexus: Uncertainty, innovation, and allocation. Journal of Business Venturing, Volume 25, pp. 449463. 